\title{
INVESTIGATING BEYOND THE LABEL OF "HALALAN-THAYYIBAN": THE HALAL GUARANTEE SYSTEM IN LOCAL RESTAURANT
}

\author{
Martini Dwi Pusparini ${ }^{1^{*}}$, Herman Setiaji ${ }^{2}$ \\ *Corresponding author: \\ ${ }^{1}$ Department of Islamic Economics, Faculty of Islamic Studies, Universitas Islam Indonesia. martini.dwi@uii.ac.id \\ ${ }^{2}$ Department of Islamic Economics, Faculty of Islamic Studies, Universitas Islam Indonesia. setiajiherman@gmail.com
}

\begin{abstract}
For Muslims, Islamic business ethics is an absolute thing to be applied in business activities. Yogyakarta is a province that consists of Muslims in majority, having potentials of requiring halal products. This research aimed at finding the implementation of Islamic business ethics in the halal and thayyib guarantee system on the offered products in order to discover the implementation of the halal labeling applied. This research was a descriptiveexplorative study using qualitative approach. The research was conducted by interviewing the managers and cook of the restaurant using in-depth interview. It was found out from the results of the study that the Ayam Penyet Surabaya Restaurant has carried out good implementation of Islamic business. In addition, regarding to the halal and thayyib guarantee system, the performance in the fields of halal organization, procurement, processing, transparency, and standardization towards the Standard Operating Procedure (SOP) and Halal Guarantee System $(\mathrm{SJH})$ were under control and evaluation. Both the control and the evaluation were presented in the form of halal, proportional, and secure presentation in accordance with the company standards which are based on five halal aspects in regards to product and use of materials. Their implementation was thoroughly and generally conducted in a good and structured way. The limitation of the research was the lack of sample observed, as the result only applied at one object only. For future research, the researchers should apply more than one object of research.
\end{abstract}

Keywords: Islamic business ethics, halal guarantee system, thayyib food standards.

\section{INTRODUCTION}

The development of economics is now increasingly widespread, not to mention the goods and services which are varies greatly, according to human needs in this globalization era. Therefore, effective economic activities are carried out to attract customers and earn profits. (Muniya, 2011). Business runs as a process that has become a human activity as an individual or community to seek profits and fulfill their wants and needs. But nowadays, only the materialistic concepts dominate most people, especially business people. A lot of cheating is done in order to get profit only, such as reducing scales, lying about the quality of goods, making fake offers or requests (bai al-najasy), competing unhealthily with other traders, and so on. Greed and negative thought patterns increasingly dominate business people in behaving. Because of that, every time business problems often increase, while blessing in trying to be reduced.

Islam provides solutions and rules for all aspects of life to organize and unite the community. Islam also takes into account new social phenomena and provides solutions by evaluating its principles. Islam brings stability while maintaining tradition in society and forming moral principles. (Pakeeza \& Chishti, 2012). Islam does not only regulate ritualistic worship in its various forms; but it also provides clear and clear guidelines about the rules of muamalah in its very broad context. This muamalah rule includes economic-business and finance, which is one of the pillars of human life. (Shahatah \& Dhahir, 2005) In Islam, all business or trade activities cannot be separated from ethics or moral values. The central point of 
Islamic business ethics is determining human freedom to act and be responsible in accordance with the principles in the Qur'an, between economics and morals will never be completely separated. (Qardhawi, Peran Nilai Moral dalam Perekonomian Islam, 2001)

A business activity must be carried out with ethics or norms that apply in the business community. Ethics and norms are used so that the business managers of goods and services do not violate the rules that have been set. Good business ethics will certainly have a positive impact on a society that is increasingly smart and developing, this development can not be separated from providing benefits to others, in other words the business is based on everything that is good and does not contain mudhorat, just like the halal labeled business has become something absolute in Indonesia. The business that has the label halalan thayyiban is a business showing that the business produces halal and thayyib foods. A food can be called halal and thayyib if the food is halal for consumption, good for the soul and does not endanger the body and human reason, contains substances needed by the human body and consumed in sufficient and balanced doses. (Umar, 2014).

Halal products are the main requirement in Indonesia because the population is mostly Muslims. (Sumarwan, 2011) Indonesia is a country with the largest Muslim population in the world. Of the 240 million population, 88.2\% are Muslim. (Kemenag, 2018). Muslim consumers will certainly choose products labeled halal and have registered with authorized institutions such as MUI. Halal labeled products will create trust for the community because they tend to be safer and avoid the harmful substances. In the Qur'an how to obtain halal sustenance and the good is called "halalan thayyiban", as it is mentioned in AL-Baqarah, 168. (Fu'ad, 1945).

Amid the public's anxiety over these issues, there are restaurants that use the label "halal and thayyib" as the right solution for all consumers, to provide a sense of calm and comfort as well as an Islamic concept, including food and services that have halal standardization with the development of companies that currently has many branches in big cities and has regular customers, namely the Ayam Penyet Surabaya Restaurant. The Ayam Penyet Surabaya Restaurant provides a breakthrough for consumers to consume food with halal and thayyib levels (good). Mr. Ikhwan Anshori as manager of the Ayam Penyet Surabaya restaurant in Yogyakarta explained that there are many potentials of Muslims for halal labeled food needs, considering halal food is the primary need of Muslims. In Yogyakarta, there are still restaurants that sell food that is not halal for Muslims. On the basis of this matter the application and presentation of the labeling of halalan thayyiban is used in the basis of processing and implementing the product as a priority in the culinary business. (Anshori, 2018)

\section{LITERATURE REVIEW Islamic Business Ethic}

Islamic business is an effort to develop capital for the necessities of life carried out by heeding Islamic ethics. In addition to establishing ethics, Islam also encourages humanity to develop business. (Subandi, 2000). Islamic business can also be interpreted as a series of business activities in various forms that are not limited to the number of ownership (goods / services) including profit, but are limited in how to obtain it and utilization of assets because of halal and haram rules, according to the word of Allah in QS Al-Baqarah 188. (Ahmad, 2001) 
The Prophet Muhammad (PBUH) in trading had an honest character, so the people called him Ash-Shiddiq which means true in his words and not lying. The second characteristic is also known to the Prophet namely al-amin or trusted. The ethics possessed by the prophet in trading are a) Honesty Principle, b) trustworthiness, c) fair in the scales, d) away from gharar (uncertainty), e) not carrying out a pilgrimage (hoarding), f) not doing al-ghab and tadlis (fraud), g) prioritizing maslahah and benefits. (Sampurno, 2015)

\section{Halal Assurance System}

The application of halal standards in Indonesia refers to the Halal Guarantee System issued by the Food, Drug and Cosmetics Supervision Institute of the Indonesian Ulema Council (LPPOM MUI). According to Ramlan (2018) the Halal Assurance System (SJH) is a system that elaborates, connects, modifies, and integrates Islamic sharia concepts specifically related to halal and haram, business ethics and overall management, procedures and mechanisms for planning and implementation and evaluation. For companies wishing to register halal certification to LPPOM MUI, both processing industries (food, medicine, cosmetics), slaughterhouses (RPH), restaurants, dry rooms, kitchens, they must fulfill the halal certification requirements contained in HAS 23000 documents. HAS 2300 is documents containing the requirements for halal certification of LPPOM MUI.

The following are five aspects of the halal guarantee system in HAS 23000:

a. Company policy statement about halal (halal policy)

The company's halal policy is a policy taken by companies related to halal production. The company needs to describe in detail the policies taken in connection with this halal, namely whether the company only produces halal materials or non-halal materials. What is meant by non-halal materials here are materials produced without regard to the halal aspects. When companies only produce halal materials, the implication will be very different if the company produces halal and non-halal materials. Halal policy is a headline that will determine the work direction of the company concerned. The company must formulate this halal policy clearly to be further described in the form of a Standard Operating Procedure (SOP).

b. Halal guidelines

The halal guide is a description of halal and haram according to the provisions of Islamic shari'a. Halal guidelines must be formulated in a clear, concise and detailed manner so that they are easily understood by all levels of management and employees.

c. Halal organization system

Halal management is an internal company organization that manages all functions and management activities in producing halal products. In managing these functions and activities the company can involve all departments or parts related to the halal production system, starting from the highest policy-making level to the level of technical implementers in the field. The halal organization system is an organizational system that is responsible for implementing the halal guarantee system. In the Halal Organization System an organizational structure consisting of top management representatives and related fields is included, among others: Quality Assurance (QA), 
Quality Control (QC), Purchasing, Research and Development (R\&D), Production, and warehousing.

d. Description of the critical control points for product negligence

To prevent errors and irregularities in the halal production process, companies need to know and determine the critical points of product prohibition. This critical point refers to the halal guidelines that have been made, which include the materials used to produce, as well as the stages of the process that might affect the product's prohibition. To determine critical control points, a flowchart of material must be made and verified, which is then followed by analysis, the stages of which are likely to be exposed to material contamination that causes haram

e. Internal halal audit system

The internal audit system is an auditing system carried out by the company periodically to evaluate the implementation of the halal guarantee system. Internal auditing is carried out by a halal organization team coordinated by a halal internal auditor.

\section{Halal Food Standards}

According to Ramlan (2014) food is anything that can be eaten and processed to be digested and absorbed by the body will be useful for health and survival. Food which is clearly declared haram are: carcass, blood, pork, animals slaughtered in the name other than Allah SWT, strangled animals, who are struck, gored by wild animals, animals slaughtered on the side of idols, khamar, all things dirty and haram for animals that have fangs like wild animals and who have claws like birds. In processing these materials, processors try to maintain that the material is truly halal like a business or company by certifying a product in a system called the Halal Guarantee System (SJH).

SJH are developed due to the increasing of the awareness and needs of Muslim consumers to protect themselves to avoid products that are prohibited (haram) and doubtful (syubhat) according to Islamic sharia provisions. The implementation of the Halal Assurance System (SJH) in its application must be described in writing in the form of a Halal Manual which covers five aspects:

1) Products do not contain pork and ingredients derived from pigs.

2) Products do not contain ingredients that are prohibited such as ingredients derived from human organs, blood, dirt and others.

3) All materials derived from halal animals slaughtered according to the procedures of Islamic law.

4) All storage, sales, processing, management and transportation places should not be used for pigs. If it has been used for pigs or other non-halal goods, it must first be cleaned in a manner that is regulated according to Islamic law.

5) All food and beverages that do not contain khamar. (Ramlan, 2014).

\section{Thayyib Food Standards}

The standards for thayyib products according to As'ad Umar (2014) are food and beverages that can be consumed are really good products. Whether or not the food consumed can be observed from the aspect of health, proportional, and safety. (Umar, 2014). 
a. Healthy food

Healthy food according to the interpretation of Mahali and As-Suyuthi (2013) is a food that has sufficient and balanced nutrition, healthy food is needed for the development and growth of the human body. One healthy food is recommended to be consumed like livestock (al-an'am). As the word of Allah SWT stated in QS Al-Nahl verse 5.

b. Proportional

Proportional according to Saksono (1996) is that food is eaten according to needs, in the sense that it does not exaggerate what is needed by the body and does not reduce it. Allah (SWT) forbids excessive humanity (Surat al-A'raf verse 31), including to consume something that is in accordance with what is needed by the body, because it is too excessive or to less that will result in the damage for the body. Too much eating can lead to damage to the digestive organs, narrowing of blood vessels, causing a person to become lazy and directly disrupt in daily activities and worship.

c. Safety

Safety according to the interpretation of Quraish Shihab (1997) is a food that is sacred from dirt and protected from all that is unclean. As the word of Allah SWT stated in QS Al-Maidah: 8. This verse concludes the meal order which is accompanied by a cautious command which essentially means that humans try to avoid themselves from everything that causes torture and disruption of security. In addition, food that is dirty and unclean will cause physical and spiritual illness. (Shihab, 1997)

\section{METHOD}

This research is categorized into field research, referring to the data source. Field research is empirical research where data and information are obtained from activities in research work. So, the effort to collect data is done directly by approaching the respondents either by interviewing or by observation. This type of research was chosen because the type of data collected is the primary data obtained from the respondents concerned so that to obtain the desired data the researcher must jump directly into the field.

This research is descriptive explorative. Descriptive research is intended to explore and clarify a phenomenon or social reality by describing a number of variables relating to the problem and the unit under study. This research is intended to describe the implementation of Islamic business practices on halal and thayyib labels in Ayam Penyet Surabaya Restaurant.

The primary data of this study were obtained through in-depth interviews with managers, cashiers, head of the warehouse, head of production, one of the Surabaya Penyet Ayam Restaurant servants and consumers or buyers from the Ayam Penyet Restaurant in Surabaya. This study uses data analysis techniques used in qualitative research including transcripts of interviews, data reduction, analysis, data interpretation, triangulation, and drawing conclusion.

\section{RESULT AND DISCUSSION}

Ayam Penyet Surabaya is one of the restaurants that applied Islamic business comes with the label "halalan thayyiban" which means it guaranteed the halal concepts in both of its 
processing aspects and services. In addition, the Ayam Penyet Surabaya Restaurant has also applied Islamic business ethics in accordance with the principles of the Prophet.

\section{The Implementation of Islamic Business Ethics}

The first Islamic business ethics observed is honesty. Honesty in Ayam Penyet Surabaya Restaurant is implemented through daily evaluations by restaurant managers. The evaluation is held after the end of work hours to see whether the income results are in line with product sales (Ikhwan, 2018) Based on the results of interviews with one of the cashiers, it was stated that the daily evaluation is useful for controlling the performance of employees, one of which is reporting income earned to confirm with the products sold and anticipating fraud in revenue generation. Thus, it gained trust between the managers and the employees. (Anita, 2018).

The application of the principle of Amanah is proven through the company's vision and mission, which the restaurant commits to provide halal products (Ikhwan, 2018) The restaurant has run what has become the company's goal by maintaining a running system both in terms of management and production. It maintains the mandate given by the company to realize what has become the vision and mission of the company (Karya, 2018).

Third, the trade ethics applied by the Ayam Penyet Surabaya Restaurant is justice. Every customer gets the same service where there is no special treatment for customers who have higher social status. In addition, aspects of justice can also be seen from the side of employee welfare where the performance given is equal to the salary earned (Ikhwan, 2018). In addition, the services provided are quite good, friendly and polite in a manner that makes customers comfortable (Riko, 2018)

The fourth, the trade ethics applied by the Ayam Penyet Restaurant in Surabaya is to avoid gharar (uncertainty). Running the system in accordance with the Standard Operating Procedure (SOP) which has been implemented which has been explained in detail, the Ayam Penyet Surabaya Restaurant provides a correlation between price and product quality which is presented with transparency describing the food components on each menu so that customers are able to know the dishes listed according to the dishes served (Ikhwan, 2018) Customers can assess the quality of the food both in its taste and appearance, whether it is in accordance with the set price. If there are differences in taste, appearance, and in terms of price the customer can complain to the employee on duty and will be replaced or the price adjusted again with the price list on the menu (Sri, 2018)

The fifth principle is not to do hoarding. Managers always carry out daily evaluations that are useful for monitoring whether there is accumulation of raw materials in the warehouse by controlling the ingredients. It was done every day after working hours to ensure that the materials needed for food production or drinks are not experiencing shortages or excess materials and have been adjusted to the budget that has been made every day (Afros, 2018)

Ayam penyet Surabaya Restaurant also does not commit fraud. It is done by showing the entire list of food and beverage prices on the existing menu list so that customers can adjust the menu list equal to the amount that must be paid to the cashier so that customers do not feel cheated (Ikhwan, 2018). Another Islamic business ethics that has been applied is prioritizing maslahah (benefits). A good management system at the Ayam Penyet Restaurant Surabaya does 
not only prioritize how to get profits but also pay attention to how the business is able to have a positive impact or benefit for the surrounding community (Ikhwan, 2018). This can be seen for example through the activities of distributing assistance in the form of basic necessities to 10 poor people around. This is done as an effort to maintain gratitude to Allah for the income earned (Karya, 2018)

\section{Halal Guarantee System in Ayam Penyet Surabaya Restaurant}

a. Halal Policy

In doing business or business, companies need to have a Standard Operating Procedure (SOP) to determine the direction of company policies related to halal production. The restaurant already has an attachment between the SOP that runs both in terms of material and storage has a standardization of halal permits to measure the criteria of MUI institutions as supporting the implementation of SOPs determined for the products presented (Ikhwan, 2018). Based on observation, the SOP has been implemented properly. for example in the case of warehousing when there is a raw material such as cooking oil that is not suitable for use it will be replaced with a new one. In addition, storage and production are always kept clean.

The Standard Operating Procedure (SOP) was delivered during the training period at the center of the Ayam Penyet Surabaya Restaurant, starting from the procedures for using halal production materials and sterilized storage, meaning that the use of a place such as a freezer is only for one raw material. (Sri, 2018).

b. Halal Guidelines

A halal guide to the products of the Restaurant is applied to each production system, both from material selection, processing and presentation. All of these have been adjusted to the Halal Guarantee System set by the MUI as the main reference for implementing halal systems in Indonesia. (Ikhwan, 2018) SOPs in Ayam Penyet Surabaya have been correlated with Halal Guarantee System from MUI institutions. Then the SOP was socialized by the captain area during the training period before the employment contract, starting from the use of materials, processes, to presentation. This ensures that the halal guidelines outlined in the SOP are well understood and implemented. (Sri, 2018).

c. Halal Organization System

The Ayam Penyet Surabaya Restaurant has a well-integrated system in halal organizational fields carried out by top management representatives and halal auditor contributions to comply with the SOP. The halal organizational fields have a correlation with the internal organizational structure to guarantee and be responsible for the LPPOM MUI. The restaurant arranged the organization field including the Quality Assurance, Quality Control, purchasing, research and development (R\&D), production, and warehousing.

d. Description of the critical control points for product negligence

One of the efforts to prevent haram things from products is by controlling the entire process starting from the use of materials and places to be used for production, so 
that the products produced are protected from prohibited ingredients. In controlling centralized halal product standards, control of materials and places to be used in the production process for re-viewing is appropriate and in accordance with the applicable Standard Operating Procedure (SOP). (Karya, 2018)

e. Internal Halal Audit System

In the internal audit system, Ayam Penyet Surabaya Restaurant evaluates the implementation of the Standard Operating Procedure (SOP) which has been synchronized with the halal guarantee system of the MUI institution in order to maintain consistency in the quality of halal products. The internal audit at the Ayam Penyet Surabaya Restaurant was carried out by the captain area and the central representative of the Restaurant (trainer area). This runs every month where the results will be reported to the head office. The policy was intended that the running system had no difference to the Standard Operating Procedure (SOP) that was implemented. But if there is a difference in the running system, the person in charge of production (head of production) will be reprimanded and given direction.

\section{Halal Food Standards}

In providing comfort to consumers, Ayam Penyet Surabaya Restaurant have had MUI halal certification with No Certificate 18160000240116 as a guarantee that the products processed are halal products. Halal-certified companies from MUI are required to create a system that is useful for maintaining the production process so that the resulting products remain consistently halal. This system is called the Halal Guarantee System (SJH) in which the company is obliged to apply Islamic concepts and business ethics to run according to established standards. (Ramlan, 2014). The application of the halal guarantee system at Ayam Penyet Surabaya Restaurant is as follows:

a. Products are free from haram ingredients such as pork. The quality of halal quality of the products of the Ayam Penyet Surabaya Restaurant is maintained because the production materials use halal materials according to Islam and the MUI institution.

b. Products do not contain ingredients that are prohibited such as ingredients derived from human organs, blood, dirt and others. In processing food and beverage products, the Ayam Penyet Surabaya Restaurant only uses halal ingredients. the use of materials in production is only permissible by Islam (halal) and instant materials used only what is labeled halal by the MUI institution.

c. All materials derived from halal animals slaughtered according to the procedures of Islamic law. The restaurant sees firsthand the process of slaughtering chickens, ducks, etc. to ensure slaughter is carried out in accordance with Islamic principles.

d. All storage, sales, processing, management and transportation places should not be used for pigs. Storage, sales, processing and transportation at the Ayam Penyet Restaurant in Surabaya are always cleaned up and maintained by the rules and regulations that are in the Islamic Shari'a by not being used for ingredients that can prohibit their products.

e. All food and beverages that do not contain khamar. Restaurants do not use 
chemical-containing ingredients from the liquor industry to emphasize consistency in maintaining the quality of halal products.

The application of a halal guarantee system covering all products, materials, storage, processing, and sales is described in writing in the form of halal manuals that contribute to each other to make a product good for the substance and does not have a negative effect on the body. In Al-qur'an Allah SWT affirms in His word (QS Al-Maidah verse 3) regarding all the materials and processes in which the goods are said to be unclean as well as all processes to make the products halal for all the Ummah.

\section{Thayyib Food Standards}

As one of the restaurants that uses the labeling "halalan thayyiban" there is certainly a standard that is done by Ayam Penyet Surabaya Restaurant. This is done to maintain the security of the processed products.

The standards of customs that have been implemented are as follows:

a. Healthy Food

According to Umar (2014), thayyib food means that the food must be healthy or have adequate and balanced nutrition. The production process at Ayam Penyet Surabaya Restaurant has provisions in the use of the amount of the ingredients so that the product has sufficient and balanced nutritional content. In addition, the ingredients used are of the best and freshest quality to produce healthy food consumed.

The provision for each material produced has been determined by the head office in accordance with the SOP. As the raw material comes from the supplier or the market is immediately sorted, which is either directly stored and the less well removed immediately. Ingredients such as vegetables are replaced every day. All materials that are not suitable for use are discarded and replaced with new ones, even though they have not reached one day. It was done to ensure the product presented to the customer is all healthy and fresh.

In this case, Islam recommends consuming foods that have sufficient and balanced nutrition, because of healthy food for the development and growth of the body. One of them is by consuming food from livestock. (QS. An-Nahl:5)

b. Proportional

Consuming enough portions of food is not excessive or lacking is the standard in the presentation of Ayam Penyet Surabaya Restaurant products by providing proportional portions. Because by consuming food that suits the needs of good for the health of the human body. As with health standards, in the presentation of products, the portion has also been determined by the head office to guarantee its proportionality.

In this case, it is in accordance with proportional food where Islam recommends consuming foods that are in accordance with their needs, meaning that they are not exaggerated from what is needed by the body and are not lacking.(QS Al-'Araf ayat 31)

c. Secure

The safety level of processed restaurant products is a priority for the Restaurant. Food must be pure from dirt and avoid all that is unclean. This, in order to get processed 
products that are truly thayyib in accordance with the standards set at the restaurant.

For example, the head of production first approached the relevant supplier to see the feasibility and cutting process in accordance with the applicable standard (Afros, 2018).

\section{CONCLUSION}

After conducting research on the halal and thayyib guarantee system in Ayam Penyet Surabaya, the conclusions are as follows:

The Ayam Penyet Surabaya Restaurant has implemented Islamic business ethics by implementing trade ethics, both in terms of management and products sold. The Restaurant applies a halal guarantee system based on five aspects of the halal label both in terms of company policy, socializing SOPs to staff. Ayam Penyet Surabaya also runs halal organizational fields such as quality anssurance, quality control, purchasing, research and development, production, and warehousing. In addition, the internal audit is also conducted once a month by the captain area and the head office representative (trainer area). Not only that, the Ayam Penyet Surabaya Restaurant also implemented halal products based on five aspects of the halal manual, both in terms of products and the use of basic materials and additions labeled halal by MUI. In addition, in terms of location, always maintaining cleanliness and purity.

In implementing the thayyib guarantee system, the Ayam Penyet Surabaya Restaurant, which is based on healthy food, proportional and safe, has been well implemented. In terms of healthy food producing food and beverage products that have sufficient and balanced nutritional content. Then in terms of proportional presentation of products with portions that are not excessive or lacking. For further research, it is expected that this research can be used as a reference in subsequent studies with different perspectives. The research that the authors do only covers Islamic business and the implementation of a system of guaranteeing halal and thayyib in general. In the future, in-depth research needs to be done in order to get new methods that can be done in carrying out the guarantee system for halal and thayyib products.

\section{REFERENCES}

As-Sayuthi, J., \& Al-Mahali, J. (2013). Tafsir al-Qur'an al-Adhim Lil Imam al-Jalalain. Semarang: Toha Putra tt.

Barus, E. E., \& Nuriani. (2016). Implementasi Etika Bisnis Islam, 2(September) , 125-146. Retrieved from http://jurnal.unsyiah.ac.id/JPED/article/view/6690\%0D\%0A

Djakfar, \& Muhammad. (2008). Etika Bisnis Islam Tataran Teori Dan Praktis. Malang: UIN Malang Press.

Djunaeni, M. E. (2015). Etika Bisnis Syariah, 1-21. Retrieved from http://id.portalgaruda.org/ index.php? page $=5 \&$ ipp $=10 \&$ ref $=$ browse $\& \mathrm{mo}=$ viewjournal $\&$ journal $=9459$

Elseidi, R. (2018). Determinants of halal purchasing intentions: evidences from UK. Journal of Islamic Marketing. 9(1):00-00. DOI: 10.1108/JIMA-02-2016-0013 
Fatkhurohmah. (2015). Pengaruh Pemahaman Label Halal dan Faktor Sosial Terhadap Niat Membeli Produk Makanan Kemasan Berlabel Halal, 1-77. Retrieved from http:// eprints.uny.ac.id/24694/1/SKRIPSI.pdf

Fauzan, \& Nuryana, I. (2014). Kepuasan Pelanggan Warung Bebek, 38-55. Retrieved from http://ejournal.unikama.ac.id/index.php/JEKO/article/download/774/47/

Fitri Amalia. (2013). ETIKA BISNIS ISLAM: Konsep dan Implementasi pada Pelaku Usaha Bisnis, (November), 116-125. Retrieved from http://journal.uinjkt.ac.id/index.php/ iqtishad/article/view/1373

Fu'ad, M. A. B. (1945). Mutiara Hadist Shahih Bukhari Muslim. PT. Bina Ilmu.

Herliani, Y. (2016). Pengaruh Perilaku Konsumen dan Label Halal Produk Makanan Rumah Tangga Terhadap Keputusan di Palangkaraya, (November), 1-106. Retrieved from http://e-journal.iain-palangkaraya.ac.id/index.php/qardh/article/view/827

Huberman, M. (1992). Analisis Data Kualitatif. Jakarta: Universitas Indonesia Press.

Kartubi. (2013). Keutamaan Mengkonsumsi Makanan Halalan Thayyiban, 58-67. Retrieved from https://studylibid.com/doc/471789/keutamaan-mengkonsumsi- makanan-halalanthayyiba

Kemenag. (2018). Kemenag Terima Promoting Indonesia Islamic Higher Education. Oktober, 31, 2018. Retrieved from https://kemenag.go.id/berita/read/302900

LPPOM MUI. (2008). Panduan Umum Sistem Jaminan Halal LPPOM-MUI, (Agustus), 1-36. Retrieved from http://www.halalmui.org/images/stories/pdf/sjh-indonesia.pdf

Muhammad, \& Fauroni, L. (2002). Visi al-Qur'an tentang Etika dan Bisnis. Jakarta: Salemba Diniyah.

Muniya Alteza, M. S. (2011). Pengantar Bisnis: Teori dan Aplikasi di Indonesia. Yogyakarta: Fakultas Ilmu Sosial dan Ekonomi Universitas Negri Yogyakarta.

Nawawi, Dan, H., \& Hadari, M. M. (1995). Instrumen Penelitian Bidang Sosial. Yogyakarta: Gadjah Mada University Press.

Ramlan, \& Nahrowi. (2014). Sertifikasi Halal Sebagai Penerapan Etika Bisnis Islam dalam Upaya Perlindungan Bagi Konsumen Muslim, 145-154. Retrieved from http://journal. uinjkt.ac.id/index.php/ahkam/article/view/1251

Saksono, L. (1996). Al-Qur'an Sebagai Obat dan Penyembuhan Melalui Makanan. Bandung: Al-Ma'arif.

Sampurno, W. M. (2015). Dampak Penerapan Etika Bisnis Terhadap Kemajuan Bisnis Home Industry pada Perusahaan, 1-21. Retrieved from https://dspace.uii.ac.id/ handle/123456789/2144

Shihab, Q. (1997). Wawasan al-Qur'an Tafsir Maudhui Atas Berbagai Persoalan Ummat. Bandung: Mizan. 
Soehartono, I. (2003). Metode Penelitian Sosial; Suatu Tehnik Penelitian Bidang Kesejahteraan Sosial dan Ilmu Sosial Lainnya. Bandung: Remaja Rosda Karya.

Sugiyono. (2008). Metode Penelitian Pendidikan: Pendekatan Kuantitatif, Kualitatif, dan R\&D, 137. Retrieved from http://thesis.binus.ac.id/Doc/Bab3Doc/2014-1-01057-MC Bab3001.doc

Sugiyono. (2010). Memahami Penelitian Kualitatif. Bandung: Alfabeta.

Sumarwan, U. (2011). PERILAKU KONSUMEN Teori dan Penerapan dalam Pemasaran. Bogor: Ghalia Indonesia.

Umar, A. (2014). Konsep Halalan Thayyiban dalam Perspektif Islam, 1, 43-63 